\title{
Creating a New Cancer Therapeutic Agent by Targeting the Interaction between $\mathrm{Bcl}-2$ and $\mathrm{IP}_{3}$ Receptors
}

\author{
Clark W. Distelhorst ${ }^{1}$ and Martin D. Bootman ${ }^{2}$ \\ ${ }^{1}$ Departments of Medicine and Pharmacology, Case Western Reserve University School of Medicine, University \\ Hospitals Cleveland Medical Center, Cleveland, Ohio 44106, USA \\ ${ }^{2}$ School of Life, Health, and Chemical Science, The Open University, Milton Keynes MK7 6AA, United Kingdom \\ Correspondence: cwd@case.edu; martin.bootman@open.ac.uk
}

$\mathrm{Bcl}-2$ is a member of a family of proteins that regulate cell survival. Expression of $\mathrm{Bcl}-2$ is aberrantly elevated in many types of cancer. Within cells of the immune system, Bcl-2 has a physiological role in regulating immune responses. However, in cancers arising from cells of the immune system Bcl-2 promotes cell survival and proliferation. This review summarizes discoveries over the past 30 years that have elucidated $\mathrm{BCl}-2$ 's role in the normal immune system, including its actions in regulating calcium $\left(\mathrm{Ca}^{2+}\right)$ signals necessary for the immune response, and for $\mathrm{Ca}^{2+}$-mediated apoptosis at the end of an immune response. How Bcl-2 modulates the release of $\mathrm{Ca}^{2+}$ from intracellular stores via inositol 1,4,5-trisphosphate receptors $\left(\mathrm{IP}_{3} \mathrm{R}\right)$ is discussed, and in particular, the role of $\mathrm{Bcl}-2 / \mathrm{IP}_{3} \mathrm{R}$ interactions in promoting the survival of cancer cells by preventing $\mathrm{Ca}^{2+}$-mediated cell death. The development and usage of a peptide, referred to as TAT-Pep8, or more recently, BIRD-2, that induces death of cancer cells by inhibiting Bcl-2's control over $\mathrm{IP}_{3} \mathrm{R}$-mediated $\mathrm{Ca}^{2+}$ elevation is discussed. Studies aimed at discovering a small molecule that mimics BIRD-2's anticancer mechanism of action are summarized, along with the prospect of such a compound becoming a novel therapeutic option for cancer.

\begin{abstract}
A principal focus of this review is on Bcl-2's physical interaction with, and regulation of, inositol 1,4,5-trisphosphate receptors $\left(\mathrm{IP}_{3} \mathrm{R}\right)$, and the prospect of targeting this interaction for cancer treatment. $\mathrm{IP}_{3} \mathrm{Rs}$ are $\mathrm{Ca}^{2+}$ channels located on intracellular organelles including the endoplasmic reticulum (ER) (Mak and Foskett 2015; Prole and Taylor 2016). Numerous extrinsic stimuli can lead to activation of the phosphoinositide signaling pathway, production of the intracellular messenger $\mathrm{IP}_{3}$, and the consequent
\end{abstract}

activation of $\mathrm{IP}_{3}$ Rs (Berridge 2016). Bcl-2 (antiapoptotic B cell lymphoma 2) is a major therapeutic target because its expression is elevated in many types of cancers, in which it contributes to malignant cell survival and chemotherapy resistance (Nougarède et al. 2018). Malignancies associated with elevated $\mathrm{Bcl}-2$ expression include $\mathrm{T}$ cell and $\mathrm{B}$ cell acute lymphoblastic leukemia, acute myeloid leukemia (AML), chronic myelogenous leukemia, diffuse large B cell lymphoma, Burkitt lymphoma, Hodgkin lympho-

Editors: Geert Bultynck, Martin D. Bootman, Michael J. Berridge, and Grace E. Stutzmann

Additional Perspectives on Calcium Signaling available at www.cshperspectives.org

Copyright (C) 2019 Cold Spring Harbor Laboratory Press; all rights reserved; doi: 10.1101/cshperspect.a035196

Cite this article as Cold Spring Harb Perspect Biol 2019;11:a035196 
C.W. Distelhorst and M.D. Bootman

ma, multiple myeloma, neuroblastoma, melanoma, meningioma, Ewing's sarcoma, and smallcell lung cancer (see broadinstitute.org/ccle/ home).

Currently, the only approved anti-Bcl-2 drug for use in cancer treatment is ABT-199/Venetoclax (Place et al. 2018), and this approval is limited to chronic lymphocytic leukemia (CLL) with some additional approvals expected to come (Fig. 1). We posit that developing an additional therapeutic agent, namely, one directed at the $\mathrm{Bcl}-2 / \mathrm{IP}_{3} \mathrm{R}$ interaction, will be a considerable advance because it would work by a totally different mechanism than that of ABT-199/Venetoclax, and may therefore be effective in malignancies already found to be resistant to ABT199/Venetoclax.

The mechanisms leading to an increase in Bcl-2 expression are known for some cancer cell types. The classic example is follicular lymphoma (FL), in which Bcl-2 levels are abnormally high because of a chromosomal translocation, $t(14 ; 18)$ (Tsujimoto et al. 1984; Bakshi et al. 1985; Cleary et al. 1986). A variety of mechanisms account for Bcl-2 elevation in other malignancies (Yip and Reed 2008). For example, Bcl-2 elevation in CLL, one of the most common malignancies associated with Bcl-2 elevation, is because of a loss of microRNAs that normally repress $\mathrm{Bcl}-2$ gene expression (Cimmino et al. 2005).

Whatever mechanism is involved in an elevated expression of $\mathrm{Bcl}-2$, numerous studies have shown that part of the ensuing increased cell survival arises because of a modulation of cellular $\mathrm{Ca}^{2+}$ signaling by Bcl-2 (Distelhorst and Bootman 2011; Greenberg et al. 2014; Vervliet et al. 2016; Distelhorst 2018). This review proceeds in a chronological manner through the elucidation of $\mathrm{Bcl}-2 / \mathrm{IP}_{3} \mathrm{R}$ interaction, the modulation of $\mathrm{Ca}^{2+}$ signaling by $\mathrm{Bcl}-2$, and ends with a discussion of the current development of small molecules that can modify the $\mathrm{Bcl}-2 / \mathrm{IP}_{3} \mathrm{R}$ interaction and thereby possess therapeutic potential for the treatment of cancer.

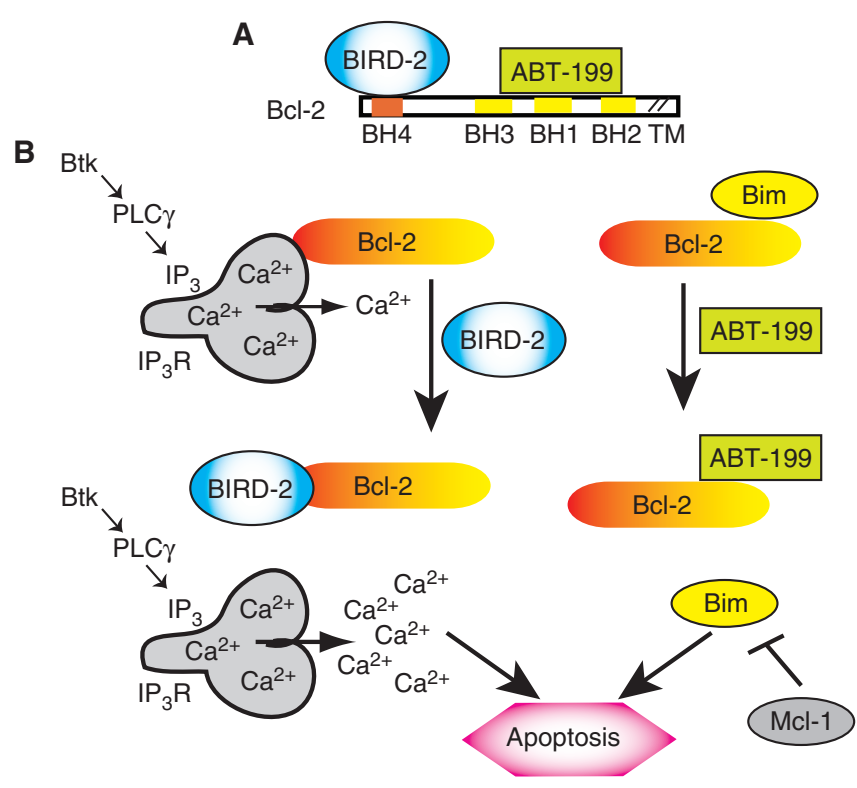

Figure 1. Targeting Bcl-2's dual antiapoptotic mechanisms. (A) BIRD-2 binds to the BH4 domain of Bcl-2. ABT-199 binds to the hydrophobic domain of Bcl-2 located in BH domains 1-3. (B) (Left) By binding to Bcl2's BH4 domain, BIRD-2 inhibits $\mathrm{Bcl} / 2-\mathrm{IP}_{3} \mathrm{R}$ interaction, inducing cytoplasmic $\mathrm{Ca}^{2+}$ elevation and apoptosis. (Right) By binding to Bcl-2's hydrophobic groove, ABT-199 displaces proapoptotic proteins, such as Bim, triggering apoptosis. But Bcl-2 relatives such as Mcl-1 can sequester Bim, and thereby be responsible for ABT199 resistance. 
Creating Cancer Therapeutics Targeting $\mathrm{Bcl}-2 / \mathrm{IP}_{3} \mathrm{R}$ Interactions

\section{THE Bcl-2 PROTEIN FAMILY}

Bcl-2 is the founding member of a protein family involved in maintaining cellular homeostasis. Bcl-2 family members can play opposing roles; on the one hand, some family members promote cell survival, whereas others can trigger apoptotic cell death. Thus, family members are generally branded either antiapoptotic (e.g., Bcl-2, Bcl-xl, Mcl-1) or proapoptotic (e.g., Bim, Bax). Within cells, antiapoptotic Bcl-2 family members bind to their proapoptotic relatives, and thereby prevent activation of cell death. If there is an increased expression of proapoptotic Bcl-2 family members, or if these proteins escape from the control of their antiapoptotic counterparts, they can then trigger cell death. For example, the proapoptotic protein Bim can be sequestered, and neutralized, by the antiapoptotic Bcl-2 protein. Release of Bim from Bcl-2, or overcoming the ability of Bcl-2 to buffer cellular levels of Bim, leads to the interaction of Bim with the proapoptotic protein Bax, which consequently causes the release of cell death-inducing factors from mitochondria. The expression level, or activity, of these functional classes of Bcl-2 family proteins is critical in determining the balance between cell survival and cell death.

The Bcl-2 protein was discovered more than 30 years ago (Tsujimoto et al. 1984; Bakshi et al. 1985; Cleary et al. 1986; Tsujimoto and Croce 1986). Soon thereafter, Bcl-2 was found to regulate cell survival by inhibiting apoptotic cell death (Vaux et al. 1988). Bcl-2 is a relatively small $(26 \mathrm{kDa})$ integral membrane protein residing on the ER and outer mitochondrial membrane (Youle and Strasser 2008; Chipuk et al. 2010). It is anchored on these membranes by a carboxy-terminal transmembrane domain and is mainly cytoplasmic in its location. Antiapoptotic Bcl-2 family members, such as Bcl-2 itself, typically have four Bcl-2 homology $(\mathrm{BH})$ domains (BH1-4). Proapoptotic Bcl-2 family members fall into two groups: those with three $\mathrm{BH}$ domains (BH1-3; the "multidomain proapoptotic Bcl-2 proteins"), and those with only a $\mathrm{BH} 3$ domain (the "BH3-only Bcl-2 proteins"). These distinctions are useful from an operational standpoint, although they undergo revision and clarification over time (Chipuk et al. 2010; Aouacheria et al. 2013).

\section{BCl-2 AND THE IMMUNE SYSTEM}

Bcl-2 is widely expressed in tissues and may play other roles in addition to promoting cell survival, such as altering mitochondrial morphology and energetics (Gross 2016). Within cells of the immune system, Bcl-2 is known for its role in regulating immune responses and self-tolerance. Bcl-2 levels fluctuate widely during $\mathrm{T}$ cell development, and during an immune response (Hockenberry et al. 1991; Andjelic et al. 1993; Gratiot-Deans et al. 1993; Veis et al. 1993a; Linette et al. 1994). The Bcl-2 knockout mouse, developed in the laboratory of the late Stanley Korsmeyer, revealed fulminant apoptosis in lymphocytes (Veis et al. 1993b). Enforced expression of Bcl-2 in transgenic mice, on the other hand, reduced negative selection, causing excessive accumulation of thymocytes (Strasser et al. 1991, 1994; Siegel et al. 1992). Bcl-2 levels are low during the process of negative selection in the thymus gland (Hogquist 2001; Neilson et al. 2004). In cells undergoing positive selection, Bcl-2 levels increase, protecting cells from apoptosis during antigenic responses. Then, when the immune response wanes, Bcl-2 levels decline, permitting apoptosis to ensue. During negative selection, low levels of $\mathrm{Bcl}-2$ permit $\mathrm{Ca}^{2+}$-dependent up-regulation of Bim, thereby triggering apoptosis (Cante-Barrett et al. 2006). This observation is critically important for the later discussion of the role of $\mathrm{Bcl}-2$ in cancer cells; Bim is a mediator of cell death, and elevated levels of Bcl-2 promote cell survival by sequestering Bim and repressing Bim expression.

\section{Bcl-2's ROLE ON THE ER}

As mentioned above, $\mathrm{Bcl}-2$ is located on both the outer mitochondrial membrane and the ER. Because of the central role of mitochondria in cell death processes, interest in the prosurvival action of Bcl-2 generally focused on these organelles and how Bcl-2 supports their function and integrity to prevent Bax-mediated apoptosis. That is, until David Andrews's laboratory stud- 
ied the effects of selectively targeting $\mathrm{Bcl}-2$ to either the mitochondria or the ER (Zhu et al. 1996). These experiments revealed differences among cell types in terms of the efficacy of mitochondria-targeted $\mathrm{Bcl}-2$ versus ER-targeted $\mathrm{Bcl}-2$ in inhibiting Bax-mediated apoptosis. Using similar methods to selectively localize Bcl-2 on the mitochondria or the ER, the Distelhorst laboratory also found that ER-targeted Bcl-2 was effective at inhibiting Bax-mediated apoptosis (Wang et al. 2001; Thomenius et al. 2003). These studies were insightful because the prosurvival action of ER-targeted Bcl-2 raised the possibility of $\mathrm{Bcl}-2$ having functions that were discrete from preventing activation of Bax on mitochondrial membranes. Indeed, these data suggested that Bcl-2 had important actions when localized to the ER membrane.

Numerous studies have shown that $\mathrm{Bcl}-2$ plays a central role in preserving $\mathrm{Ca}^{2+}$ homeostasis and preventing $\mathrm{Ca}^{2+}$-mediated apoptosis (Zhang et al. 2001; Pinton et al. 2002; Hanson et al. 2008b; Rong and Distelhorst 2008; Vervloessem et al. 2018). The location of Bcl-2 on the ER membrane places it in close proximity to pumps and channels that are responsible for $\mathrm{Ca}^{2+}$ sequestration and the generation of cytosolic $\mathrm{Ca}^{2+}$ signals. The ER is the major constitutive $\mathrm{Ca}^{2+}$ store in most cell types, and is a source of $\mathrm{Ca}^{2+}$ for important signaling events such as gene transcription. Various extrinsic stimuli can trigger the release of $\mathrm{Ca}^{2+}$ from $\mathrm{IP}_{3} \mathrm{R}$ channels located on the ER membrane, thereby causing an increase in cytosolic $\mathrm{Ca}^{2+}$ concentration. Typically, stimulation of cells leads to repetitive cytosolic $\mathrm{Ca}^{2+}$ oscillations: rapid, transient, increases in cytosolic $\mathrm{Ca}^{2+}$ concentration that are sensed by $\mathrm{Ca}^{2+}$-binding proteins and lead to activation of cellular effectors (Berridge 2009). The diffusion of $\mathrm{Ca}^{2+}$ ions within a cell during each $\mathrm{Ca}^{2+}$ oscillation delivers information throughout the cytoplasm, and also into mitochondria and the nucleus, thus regulating a wide variety of cellular processes, including cell survival and cell death (Berridge 1997; Lewis 2003; Gallo et al. 2006; Fracchia et al. 2013).

A number of observations were critical in linking Bcl-2 that was localized on the ER to regulation of $\mathrm{Ca}^{2+}$ signaling and homeostasis:
1. A flux of $\mathrm{Ca}^{2+}$ from the ER lumen into the cytoplasm accompanied cell death induction in glucocorticosteroid hormone-treated lymphoma cell lines (McConkey et al. 1989; Lam et al. 1992, 1993).

2. Apoptosis induced by withdrawal of interleukin-3 (IL-3) from an IL-3-dependent hematopoietic cell line was associated with repartitioning of intracellular $\mathrm{Ca}^{2+}$ between organelles, and was blocked by enforced Bcl2 expression (Baffy et al. 1993).

3. In thymocytes, sensitivity to $\mathrm{Ca}^{2+}$-mediated negative selection was associated with, and enabled by, Bcl-2 down-regulation (Andjelic et al. 1993).

4. Bcl-2 overexpression inhibited apoptosis by reducing $\mathrm{Ca}^{2+}$ release from the ER following glucocorticosteroid treatment of a T cell leukemia cell line (Lam et al. 1994; Sobecks et al. 1996; He et al. 1997).

5. Whereas, induction of apoptosis mediated by $\mathrm{N}$-myc required normal $\mathrm{Ca}^{2+}$ levels, apoptosis prevention conferred by Bcl-2 correlated with the inhibition of intracellular $\mathrm{Ca}^{2+}$ fluxes. This led to the hypothesis that regulation of intracellular $\mathrm{Ca}^{2+}$ concentration is an important aspect of the oncogenic cooperation between Bcl-2 and N-myc (Zornig et al. 1995).

\section{Bcl-2/IP ${ }_{3}$ R INTERACTION}

Novel insight into how $\mathrm{Bcl}-2$ regulates $\mathrm{Ca}^{2+}$ homeostasis and $\mathrm{Ca}^{2+}$ signaling came from work initiated by the Distelhorst laboratory, some of which was performed during fruitful collaborations with others. Distelhorst and colleagues described, for the first time, a physical interaction between $\mathrm{Bcl}-2$ and $\mathrm{IP}_{3}$ Rs that repressed anti$\mathrm{CD} 3$-mediated $\mathrm{Ca}^{2+}$ release from the ER in T cells (Fig. 1; Chen et al. 2004; Hanson et al. 2004, 2008a). These initial findings have been extended to other members of the Bcl-2 protein family by studies showing that not only Bcl-2, but also Bcl-xl and $\mathrm{Mcl}-1$ can modulate $\mathrm{Ca}^{2+}$ release from the ER (White et al. 2005; Eckenrode et al. 2010; Vervliet et al. 2016). 
Using both cell population measurements and single cell imaging to monitor cytosolic $\mathrm{Ca}^{2+}$ levels, it was observed that Bcl-2 inhibited anti-CD3-induced $\mathrm{Ca}^{2+}$ elevation in multiple Bcl-2-expressing clones of the WEHI7.2 T cell line (Chen et al. 2004). The inhibitory effect of $\mathrm{Bcl}-2$ on $\mathrm{ER} \mathrm{Ca}^{2+}$ release was detected when the phosphoinositide signaling pathway mediating anti-CD3-induced $\mathrm{IP}_{3}$ synthesis was bypassed by adding a cell-permeant $\mathrm{IP}_{3}$ ester to cells, or by adding $\mathrm{IP}_{3}$ to digitonin-permeabilized cells. The anti-CD3-induced $\mathrm{Ca}^{2+}$ elevation in T cells was not only inhibited by wild-type Bcl-2, which localizes to both the ER and mitochondria, but also by Bcl-2 selectively targeted to the ER membrane. In subsequent studies, summarized in depth below, we further verified $\mathrm{Bcl}-2 / \mathrm{IP}_{3} \mathrm{R}$ interaction using fluorescence resonance energy transfer (FRET)-based assays (Rong et al. 2008). Taken together, these findings indicated that the action of Bcl-2 in inhibiting cellular $\mathrm{Ca}^{2+}$ signals resides at the level of the ER, rather than in the upstream signal transduction pathway that mediates $\mathrm{IP}_{3}$ synthesis. Importantly, a series of control experiments indicated that inhibition of $\mathrm{IP}_{3}$-induced $\mathrm{Ca}^{2+}$ release by $\mathrm{Bcl}-2$ was not a result of decreased ER luminal $\mathrm{Ca}^{2+}$ concentration, decreased $\mathrm{IP}_{3} \mathrm{R}$ levels, or altered expression of luminal $\mathrm{Ca}^{2+}$-binding proteins. Although there is a decrease in the affinity of $\mathrm{IP}_{3} \mathrm{Rs}$ for $\mathrm{IP}_{3}$ in T cells expressing $\mathrm{Bcl}-2$, it has been found that $\mathrm{Bcl}$ 2 inhibited $\mathrm{IP}_{3}$-induced $\mathrm{Ca}^{2+}$ release even at saturating $\mathrm{IP}_{3}$ concentrations (Chen et al. 2004). These observations indicated that the inhibition of $\mathrm{Ca}^{2+}$ release by $\mathrm{Bcl}-2$ has at least two components: a decrease in the affinity of $\mathrm{IP}_{3} \mathrm{Rs}$ for $\mathrm{IP}_{3}$ and reduced $\mathrm{IP}_{3} \mathrm{R}$ channel opening even under conditions of maximal stimulation.

An intriguing aspect of the action of $\mathrm{Bcl}-2$ is that it differentially regulates $\mathrm{Ca}^{2+}$ signals according to the strength of $\mathrm{T}$ cell receptor activation (Zhong et al. 2006). High concentrations of anti-CD3 antibodies (used to evoke T cell receptor activation) induce a longer-lasting cytosolic $\mathrm{Ca}^{2+}$ elevation, with a greater peak amplitude, than low anti-CD3 antibody concentrations. The large, sustained cytosolic $\mathrm{Ca}^{2+}$ elevations caused by strong $\mathrm{T}$ cell receptor activation are proapoptotic. Whereas, the lesser cytosolic $\mathrm{Ca}^{2+}$ signals caused by weaker $\mathrm{T}$ cell activation are prosurvival. These findings are consistent with the work of many investigators regarding the characteristics of $\mathrm{Ca}^{2+}$ elevations capable of mediating cell death (Szalai et al. 1999; Hajnóczky et al. 2000, 2003; Lin et al. 2005; Joseph and Hajnóczky 2007).

Strikingly, Bcl-2 was found to inhibit the proapoptotic sustained $\mathrm{Ca}^{2+}$ elevations induced by strong $\mathrm{T}$ cell receptor activation, while enhancing the prosurvival $\mathrm{Ca}^{2+}$ oscillations induced by weaker $\mathrm{T}$ cell receptor activation (Zhong et al. 2006). It is not fully clear how Bcl-2 has this duality of action, and it might seem surprising from a simple bimolecular interaction between two constitutively bound proteins. However, continuing studies have shown that $\mathrm{Bcl}-2$ can act to dock additional proteins at $\mathrm{IP}_{3}$ Rs (see below), thereby raising the possibility that the regulation of $\mathrm{IP}_{3} \mathrm{Rs}$ by $\mathrm{Bcl}-2$ is dependent on multiple players. Whatever the mechanism, these observations emphasize the point that Bcl-2 functions to enhance cell survival and can have this action by either dampening large cytosolic $\mathrm{Ca}^{2+}$ elevations or promoting lesser cytosolic $\mathrm{Ca}^{2+}$ signals.

\section{TARGETING BCl-2/IP ${ }_{3}$ R INTERACTION WITH A SYNTHETIC PEPTIDE}

To develop an experimental tool for use in identifying the functional role of the $\mathrm{Bcl}-2 / \mathrm{IP}_{3} \mathrm{R}$ interaction, we mapped the $\mathrm{Bcl}$-2-binding site to a 20 amino acid sequence in domain 3 of type $1 \mathrm{IP}_{3} \mathrm{R}$, which is located in a portion of the channel known as the "regulatory and coupling region" (Fig. 1; Rong et al. 2008). A synthetic peptide mimicking the $\mathrm{IP}_{3} \mathrm{R}$ sequence within domain 3 binds $\mathrm{Bcl}-2$ and functions as a decoy peptide in that it displaces $\mathrm{Bcl}-2$ from the $\mathrm{IP}_{3} \mathrm{R}$. This peptide, referred to as TAT-Pep2, abrogates Bcl-2's inhibition of $\mathrm{IP}_{3} \mathrm{R}$-mediated $\mathrm{Ca}^{2+}$ release, thereby exaggerating cytosolic $\mathrm{Ca}^{2+}$ signals and triggering apoptotic cell death (Rong et al. 2008). These findings were consolidated by showing effects of TAT-Pep2 (or just Pep2 without the TAT conjugate that allows the protein to be membrane-permeating) on $\mathrm{IP}_{3} \mathrm{R}$ channel activity in vitro, $\mathrm{IP}_{3}$-induced ER 
$\mathrm{Ca}^{2+}$ release in permeabilized cells, and cellpermeable $\mathrm{IP}_{3}$ ester-induced $\mathrm{Ca}^{2+}$ elevation in intact cells. Bcl-2's inhibition of T cell-receptorinduced $\mathrm{Ca}^{2+}$ elevation and apoptosis are reversed by incubation of cells with TAT-Pep2. These data confirmed that the interaction of Bcl-2 with $\mathrm{IP}_{3} \mathrm{Rs}$ contributes to the regulation of proapoptotic $\mathrm{Ca}^{2+}$ signals. Moreover, they highlighted the $\mathrm{Bcl}-2 / \mathrm{IP}_{3} \mathrm{R}$ interaction as a potential therapeutic target in diseases associated with Bcl-2's inhibition of cell death.

In continuing studies, we found the interaction of $\mathrm{Bcl}-2$ with the $\mathrm{IP}_{3} \mathrm{R}$ was mediated by the BH4 domain of Bcl-2 (Rong et al. 2009). The presence of a $\mathrm{BH} 4$ domain distinguishes the antiapoptotic protein $\mathrm{Bcl}-2$ from its proapoptotic relatives. Deletion of the $\mathrm{BH} 4$ domain converts Bcl-2 into a proapoptotic protein, whereas a TAT-BH4 peptide (i.e., a membrane-permeant form of Bcl-2's BH4 domain) inhibits apoptosis and improves survival in models of disease caused by accelerated apoptosis (Hotchkiss et al. 2006). Thus, the BH4 domain of Bcl-2 has antiapoptotic activity independent of full-length protein. It is known that the $\mathrm{BH} 4$ domain of $\mathrm{Bcl}-$ 2 is involved in the interaction with and suppression of Bax (Ding et al. 2010; Barclay et al. 2015), but in addition the $\mathrm{BH} 4$ domain of Bcl-2 and domain 3 of $\mathrm{IP}_{3} \mathrm{Rs}$ are responsible for the Bcl$2 / \mathrm{IP}_{3} \mathrm{R}$ interaction that modulates $\mathrm{Ca}^{2+}$ signaling and inhibits apoptosis. TAT-Pep2, which mimics part of the amino acid sequence of domain 3 of $\mathrm{IP}_{3} \mathrm{Rs}$, prevents the $\mathrm{Bcl}-2 / \mathrm{IP}_{3} \mathrm{R}$ interaction by providing alternative docking sites for the $\mathrm{BH} 4$ domain of Bcl-2.

The binding of Bcl-2 by domain 3 of $\mathrm{IP}_{3} \mathrm{Rs}$ was confirmed in collaboration with others, and it was also determined that a critical residue in the BH4 domain of Bcl-2 (Lys17), which is not observed in the BH4 domain of Bcl-XL (Asp11), is necessary for binding to the $\mathrm{IP}_{3} \mathrm{R}$ (Monaco et al. 2012). Additional findings indicated the $\alpha$-helical secondary structure of the BH4 domain of Bcl-2, conferred by the Ile14 and Val15 residues, is essential for inhibiting $\mathrm{IP}_{3} \mathrm{R}$-mediated $\mathrm{Ca}^{2+}$ release (Monaco et al. 2013). Moreover, in contrast to wild-type Bcl-2, a full-length Bcl-2 Ile14Gly/Val15Gly mutant displayed markedly reduced structural stability and a shortened pro- tein half-life. Also, the mutant protein failed to interact with $\mathrm{Bax}$, and was unable to inhibit $\mathrm{IP}_{3} \mathrm{R}$-mediated $\mathrm{Ca}^{2+}$ release or to protect against $\mathrm{Ca}^{2+}$-mediated apoptosis (Monaco et al. 2018).

The carboxy-terminal portion of $\mathrm{Bcl}-2$, which contains a transmembrane domain that tethers the protein to cellular membranes, also plays a role in regulating of $\mathrm{IP}_{3} \mathrm{R}$-mediated $\mathrm{Ca}^{2+}$ release and apoptosis. Deletion of the transmembrane domain of Bcl-2 yielded a protein with a lesser ability to inhibit both $\mathrm{Ca}^{2+}$ signaling and apoptosis (Ivanova et al. 2016). At first sight, this outcome might seem rather predictable. It is obvious that deletion of the transmembrane domain of Bcl-2 would prevent its insertion into ER membranes, and thereby make it less likely to be juxtaposed to $\mathrm{IP}_{3}$ Rs. However, it appears that the transmembrane domain of $\mathrm{Bcl}-2$ is not only required for locating Bcl-2 on ER membranes, but also increases the association of Bcl-2 with $\mathrm{IP}_{3} \mathrm{Rs}$. In this case, the $\mathrm{Bcl}-2 / \mathrm{IP}_{3} \mathrm{R}$ interaction is not mediated by the $\mathrm{BH} 4$ of $\mathrm{Bcl}-2$ and domain 3 of $\mathrm{IP}_{3} \mathrm{Rs}$, but by the transmembrane carboxyterminal domains of both proteins. Another striking observation was that the carboxy-terminal domain of Bcl-2 alone had an inhibitory effect on $\mathrm{IP}_{3} \mathrm{R}$-mediated $\mathrm{Ca}^{2+}$ release (Ivanova et al. 2016). The Bcl-2/IP ${ }_{3} \mathrm{R}$ interaction therefore appears to have multiple components that promote both protein:protein binding and inhibition of $\mathrm{Ca}^{2+}$ release. It is interesting to note that Bcl-2 exists in at least two isoforms, Bcl-2 $\alpha$ and $\mathrm{Bcl}-2 \beta$, which differ in that $\mathrm{Bcl}-2 \beta$ does not have the carboxy-terminal transmembrane domain and is a cytosolic protein (Ivanova et al. 2016). $\mathrm{Bcl}-2 \beta$ is typically expressed at lower levels than Bcl- $2 \alpha$, but may have a proapoptotic action that promotes tumor cell death (Warren et al. 2016), consistent with the notion that the carboxyterminal domain is necessary for interaction with $\mathrm{IP}_{3} \mathrm{Rs}$ and inhibition of apoptosis.

Through minor modification of the TATPep2 sequence, replacing two amino acids encoding a putative protease cleavage site, we improved the stability and thus the potency of this peptide inhibitor of $\mathrm{Bcl}-2 / \mathrm{IP}_{3} \mathrm{R}$ interaction (Zhong et al. 2011). This modified peptide was initially referred to as TAT-Pep8, but has been more recently named $\mathrm{Bcl}-2 \mathrm{IP}_{3} \mathrm{R}$ Disruptor-2, or 
BIRD-2. Using this modified peptide to inhibit $\mathrm{Bcl}-2 / \mathrm{IP}_{3} \mathrm{R}$ interaction in primary human CLL cells, we provided additional evidence of the therapeutic usage of inhibiting $\mathrm{Bcl}-2 / \mathrm{IP}_{3} \mathrm{R}$ interaction, as BIRD-2-treated CLL cells underwent apoptosis, whereas normal lymphocytes did not (Zhong et al. 2011). Additional evidence for the potential therapeutic value of targeting Bcl-2/ $\mathrm{IP}_{3} \mathrm{R}$ interaction using BIRD-2 has been provided since this initial study. Induction of apoptosis by BIRD-2 in diffuse large B cell lymphoma (DLBCL) cell lines (Akl et al. 2013) and in multiple myeloma cell lines in vitro and in a xenograft mouse model of multiple myeloma (Lavik et al. 2015) has been documented. Importantly, the potential value of targeting $\mathrm{Bcl}-2 / \mathrm{IP}_{3} \mathrm{R}$ interaction using BIRD-2 has been extended in recent studies to nonlymphoid malignancies, including small-cell lung cancer (Greenberg et al. 2015) and ovarian cancer (Xie et al. 2018). Finally, further recent studies indicate that BIRD-2triggered cytosolic $\mathrm{Ca}^{2+}$ signals and cell death are critically dependent on the constitutive $\mathrm{IP}_{3}$ signaling that occurs downstream from the B cell receptor in $\mathrm{B}$ cell malignancies (Bittremieux

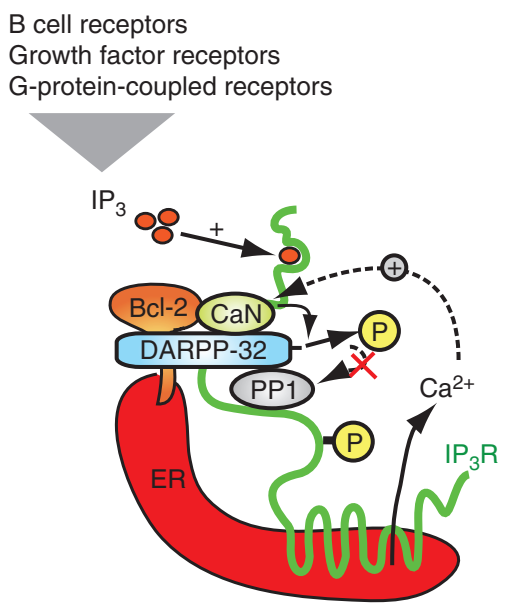

Figure 2. Bcl-2 regulates $\mathrm{IP}_{3}$-induced $\mathrm{Ca}^{2+}$ release from the endoplasmic reticulum (ER). Bcl-2 docks $\mathrm{CaN}$ and DARPP-32 onto the $\mathrm{IP}_{3} \mathrm{R}$, forming a negative feedback loop that regulates $\mathrm{IP}_{3} \mathrm{R}$ phosphorylation and prevents $\mathrm{Ca}^{2+}$ elevation that induces apoptosis. BIRD-2 inhibits Bcl-2/IP $\mathrm{I}_{3} \mathrm{R}$ interaction, inducing excessive $\mathrm{Ca}^{2+}$ elevation and apoptosis. et al. 2018a). The cell death induced by BIRD-2 is dependent on $\mathrm{Ca}^{2+}$ release from the ER via $\mathrm{IP}_{3} \mathrm{Rs}$, but also requires the presence of extracellular $\mathrm{Ca}^{2+}$ to maintain the cytosolic $\mathrm{Ca}^{2+}$ signals to drive cells to point of cell death (Bittremieux et al. 2018b). The ER Ca ${ }^{2+}$ store is finite, and when the ER is depleted influx of $\mathrm{Ca}^{2+}$ across the cell membrane is required to sustain cytosolic $\mathrm{Ca}^{2+}$ signals. It is unclear what mechanism underlies the influx of $\mathrm{Ca}^{2+}$ during BIRD2-induced cell death. In most cells, depletion of $\mathrm{ER} \mathrm{Ca}^{2+}$ content activates a "store-operated $\mathrm{Ca}^{2+}$ entry" (SOCE) mechanism to allow replenishment (Putney 2007; Bodnar et al. 2017; Bootman and Rietdorf 2017; Putney et al. 2017). However, knockdown of the SOCE component STIM1, or addition of pharmacological inhibitors, did not protect against BIRD-2-induced apoptosis (Bittremieux et al. 2018b).

\section{Bcl-2 MEDIATES A NEGATIVE FEEDBACK LOOK THAT MODULATES $\mathrm{Ca}^{2+}$ SIGNALING AND CELL DEATH}

The discussion above alluded to both direct and indirect actions of $\mathrm{Bcl}-2$ in regulating $\mathrm{IP}_{3} \mathrm{R}$-mediated $\mathrm{Ca}^{2+}$ release, and the ability of $\mathrm{Bcl}-2$ to regulate prodeath $\mathrm{Ca}^{2+}$ elevations without interfering with physiological $\mathrm{IP}_{3} \mathrm{R}$-mediated $\mathrm{Ca}^{2+}$ signals. In addition to its direct bimolecular effect on $\mathrm{IP}_{3} \mathrm{Rs}$, which has been shown, for example, using purified $\mathrm{IP}_{3} \mathrm{Rs}$ and recombinant $\mathrm{Bcl}-2$ in simple lipid bilayers (Chen et al. 2004), Bcl-2 can act to dock other proteins with $\mathrm{IP}_{3} \mathrm{Rs}$. For example, Bcl-2 docks both DARPP-32 (dopamine- and cAMP-regulated phosphoprotein of molecular weight 32,000$)$ and calcineurin (a $\mathrm{Ca}^{2+}$-sensitive phosphatase) in a complex on the $\mathrm{IP}_{3} \mathrm{R}$ (Chang et al. 2014). DARPP-32 is phosphorylated and activated by protein kinase $\mathrm{A}$ (PKA), and is dephosphorylated by calcineurin. In its phosphorylated state DARPP-32 can inhibit the activity of protein phosphatase 1 (PP1) (Walaas et al. 2011).

The association of DARPP-32 and calcineurin with $\mathrm{IP}_{3} \mathrm{Rs}$ was shown to reduce $\mathrm{IP}_{3} \mathrm{R}$ mediated $\mathrm{Ca}^{2+}$ elevation in T cells (Fig. 2; Chang et al. 2014). In brief, type $1 \mathrm{IP}_{3}$ Rs can be phosphorylated by PKA on Ser1755, thereby sensi- 
tizing the channels to $\mathrm{IP}_{3}$ and enhancing cellular $\mathrm{Ca}^{2+}$ signaling. The PKA-mediated phosphorylation of type $1 \mathrm{IP}_{3}$ Rs can be reversed by PP1, which is inhibited by PKA-phosphorylated DARPP-32. The IP ${ }_{3} \mathrm{R} / \mathrm{Bcl}-2 / \mathrm{DARPP}-32 / \mathrm{calci}$ neurin complex creates a negative feedback loop that prevents excessive $\mathrm{Ca}^{2+}$ release from the ER by regulating $\mathrm{IP}_{3} \mathrm{R}$ phosphorylation as follows. $\mathrm{Ca}^{2+}$ release arising via $\mathrm{IP}_{3} \mathrm{Rs}$ activates calcineurin, which subsequently dephosphorylates DARPP-32 thereby relieving its inhibition of PP1. Active PP1 can dephosphorylate $\mathrm{IP}_{3} \mathrm{Rs}$ and consequently attenuate $\mathrm{Ca}^{2+}$ release. So, by bringing DARPP-32 and calcineurin into close association with $\mathrm{IP}_{3} \mathrm{Rs}, \mathrm{Bcl}-2$ can indirectly contribute to the regulation of $\mathrm{IP}_{3} \mathrm{R}$ phosphorylation and $\mathrm{Ca}^{2+}$ release from the ER (Chang et al. 2014).

These findings are consistent with evidence from multiple laboratories pointing to a role of Bcl-2 in regulating $\mathrm{IP}_{3} \mathrm{R}$ phosphorylation, and thus $\mathrm{IP}_{3} \mathrm{R}$-mediated $\mathrm{Ca}^{2+}$ release. We previously reported that $\mathrm{Bcl}-2$ decreases $\mathrm{IP}_{3} \mathrm{R}$ phosphorylation (Chen et al. 2004), and other investigators found that PKA mediates phosphorylation of serine 1755 and serine 1589 on type $1 \mathrm{IP}_{3} \mathrm{Rs}$, thereby increasing $\mathrm{IP}_{3}$-mediated channel opening and $\mathrm{Ca}^{2+}$ release (Volpe and Alderson-Lang 1990; Wagner et al. 2003, 2008). Also, Oakes et al. (2005) found that $\mathrm{Bcl}-2$ regulates $\mathrm{IP}_{3} \mathrm{R}$ phosphorylation in the $\mathrm{IP}_{3} \mathrm{R}$ regulatory and coupling domain. PKA-mediated protein phosphorylation is typically regulated by $\mathrm{PP} 1 \alpha$ (Tang et al. 2003), and an $\mathrm{IP}_{3} \mathrm{R} / \mathrm{PP} 1 \alpha$ complex has been implicated in Bcl-2-mediated suppression of ER $\mathrm{Ca}^{2+}$ release in breast cancer cells (Xu et al. 2007). Also, it has been established for some time that Bcl-2 binds calcineurin (Shibasaki et al. 1997), and that Bcl-2 increases the association of calcineurin with $\mathrm{IP}_{3} \mathrm{Rs}$ (Erin et al. 2003a, b; Erin and Billingsley 2004); this has a neuroprotective effect in primary neuronal cells (Erin et al. 2003b).

Before the work described above, Bultynck and colleagues had predicted that the effects of calcineurin on $\mathrm{IP}_{3} \mathrm{R}$-mediated $\mathrm{Ca}^{2+}$ signals were indirect, and may be secondary to PP1 acting with DARPP-32 (Bultynck et al. 2003). Tang et al. (2003) discovered a direct association be- tween $\mathrm{PP} 1 \alpha$ and type $1 \mathrm{IP}_{3} \mathrm{R}$, and established that the association with $P P 1 \alpha$ reverses PKAmediated $\mathrm{IP}_{3} \mathrm{R}$ phosphorylation. AKAP9, a multifunctional PKA anchoring protein, docks both PKA and PP1 $\alpha$ to $\mathrm{IP}_{3} \mathrm{R}$ (Tu et al. 2004). In experiments with medium spiny neurons from DARPP-32 knockout mice, DARPP-32 was shown to regulate dopamine-induced $\mathrm{Ca}^{2+}$ oscillations (Tang and Bezprozvanny 2004). However, very little is known about the role of DARPP-32 in peripheral tissues, including lymphocytes, although DARPP-32 has been shown to increase the phosphorylation and activity of various ion channels (Svenningsson et al. 2004).

The findings discussed above are relevant to CLL in humans, because we detect DARPP-32 expression in primary human CLL cells. Moreover, treating these cells with BIRD-2 increases phosphorylation of Ser1755 in type $1 \mathrm{IP}_{3} \mathrm{Rs}$ levels followed by enhanced cytosolic $\mathrm{Ca}^{2+}$ elevation (Chang et al. 2014). Taken together, our data indicate that $\mathrm{BIRD}$-2-mediated disruption of the $\mathrm{Bcl}-2 / \mathrm{IP}_{3} \mathrm{R}$ interaction (and consequently, also that of DARPP-32 and calcineurin with $\mathrm{IP}_{3} \mathrm{Rs}$ ) overcomes the Bcl-2-imposed repression of Ser 1755 phosphorylation and $\mathrm{IP}_{3} \mathrm{R}$-mediated $\mathrm{Ca}^{2+}$ release. These results suggest that CLL cells exploit the $\mathrm{IP}_{3} \mathrm{R} / \mathrm{Bcl}-2 / \mathrm{DARPP}-32 /$ calcineurinmediated negative feedback mechanism to prevent $\mathrm{Ca}^{2+}$ elevation and cell death.

\section{ELUCIDATING A SMALL MOLECULE INHIBITOR THAT MIMICS BIRD-2}

The actions of the peptide inhibitors, BIRD-2 (TAT-Pep8) and TAT-Pep2, summarized here provide a strong rationale for targeting the $\mathrm{Bcl}-$ $2 / \mathrm{IP}_{3} \mathrm{R}$ interaction as a novel treatment strategy for Bcl-2-positive malignancies. However, peptides rarely become effective therapeutic agents, and a long-term aim is therefore to explore the use of small molecules as a step toward producing effective inhibitors of $\mathrm{Bcl}-2 / \mathrm{IP}_{3} \mathrm{R}$ interactions for clinical use.

To this end, the Distelhorst laboratory has conducted a high-throughput screen with the goal of identifying chemical compounds that mimic the function of BIRD-2 by binding to the $\mathrm{BH} 4$ domain of $\mathrm{Bcl}-2$ and disrupting Bcl- 
2's interaction with $\mathrm{IP}_{3} \mathrm{R}$. A library of 25,480 compounds was tested using two Bcl-2-positive multiple myeloma cell lines. A caspase activation assay (i.e., stimulation of apoptotic cell death) was performed in the initial screening procedures to detect responses to individual compounds. Of the compounds tested, 38 were positive for caspase activation, and thus advanced to additional testing in our laboratory using both the caspase assay (with myeloma lines), and an MTS cell viability assay (with both myeloma lines and in primary human CLL cells). These studies were followed by cytoplasmic $\mathrm{Ca}^{2+}$ measurements using Jurkat cells, and selected primary CLL cells, as summarized in the heat map (Fig. 3). As noted on the heat map, one of the most promising hits, labeled "lead compound," is positive across each of the assays performed. This compound not only induces cell death in the multiple myeloma cell lines, but also induces both cell death and $\mathrm{Ca}^{2+}$ elevation in Jurkat cells and CLL cells. Moreover, additional studies show that the lead compound induces cell death in additional hematologic malignancies: acute lymphoblastic leukemia, histiocytic lymphoma, multiple myeloma, and smallcell lung cancer. Moreover, this compound does not induce cell death in normal human lymphocytes (Fig. 4). Interest in this compound is enhanced by evidence it produces synergistic cell death when combined with ABT-199/Venetoclax (Fig. 5). Although this work is still in progress, requiring biophysical studies to document on-target effects and use of mouse models to document in vivo action and monitor potential toxicity, the findings encourage the prospect of developing a novel Bcl-2 inhibitor to supplement the current therapeutic ABT-199/Venetoclax.

ABT-199/Venetoclax induces apoptosis by a different mechanism to BIRD-2. Unlike BIRD2, ABT-199/Venetoclax neither binds to the $\mathrm{BH} 4$ domain of $\mathrm{Bcl}-2$, nor interacts with $\mathrm{IP}_{3} \mathrm{Rs}$, or regulates intracellular $\mathrm{Ca}^{2+}$ signaling or homeostasis (Ivanova et al. 2016; Vervloessem et al. 2017b; Jakubowska et al. 2018). Instead, ABT199/Venetoclax binds within a hydrophobic pocket formed by $\mathrm{BH}$ domains 1-3 of Bcl-2. In so doing, it displaces proapoptotic proteins, such as Bim, from Bcl-2, thereby activating Bax and inducing apoptotic cell death. Because of its fundamental mechanism of action, ABT-199/ Venetoclax is an effective therapeutic agent only in malignancies in which levels of both Bcl-2 and Bim are elevated: cells that are said to be addicted to $\mathrm{Bcl}-2$ for their survival (Letai 2008; Davids and Letai 2013).

Thus, ABT-199/Venetoclax responsiveness varies among cancers (Deng et al. 2007). For example, CLL is highly responsive to ABT-199/ Venetoclax, although resistance is reported ( $\mathrm{Da}$ vids et al. 2012). On the other hand, ABT-199/ Venetoclax response rates are $28 \%$ in DLBCL and $31 \%$ in FL (Gibson and Davids 2015). Although Bcl-2 is commonly expressed in multiple myeloma at levels comparable to CLL and FL (Pettersson et al. 1992), responses to ABT-199/ Venetoclax are limited to a small subset of myeloma lines (Touzeau et al. 2014) and patients with the CCND1/IGH translocation (Touzeau et al. 2014; Gibson and Davids 2015). Also, AML is a Bcl-2-positive malignancy, but ABT$199 /$ Venetoclax is effective in only a fraction of AML patients (Konopleva et al. 2006; Pan et al. 2014). Major reasons for ABT-199/Venetoclax resistance include (1) low expression levels of proapoptotic proteins so the cancer cells are not primed to respond to ABT-199/Venetoclax (Deng et al. 2007); and (2) expression of Mcl-1 or Bcl-xl, which bind and inhibit proapoptotic proteins released from Bcl-2 by ABT-199/Venetoclax (Choudhary et al. 2015).

Interestingly, a reciprocal relationship was observed in the sensitivity of cancer cell lines to ABT-199/Venetoclax and BIRD-2 (Greenberg et al. 2015; Lavik et al. 2015; Vervloessem et al. 2017a). These observations are consistent with Bcl-2 having different prosurvival modes of action: one by sequestering proapoptotic proteins (ABT-199/Venetoclax sensitive) and another by reducing $\mathrm{Ca}^{2+}$ release from $\mathrm{IP}_{3} \mathrm{Rs}$ (BIRD-2 sensitive). These two modes of action may be linked because incubation of cells with BIRD-2 increases Bim expression in cancer cells that have relatively low Bim levels and thus are insensitive to ABT-199/Venetoclax (Greenberg et al. 2015; Lavik et al. 2015). It is therefore plausible that BIRD-2, or a small molecule with analogous interactions, can trigger cell death either 
C.W. Distelhorst and M.D. Bootman

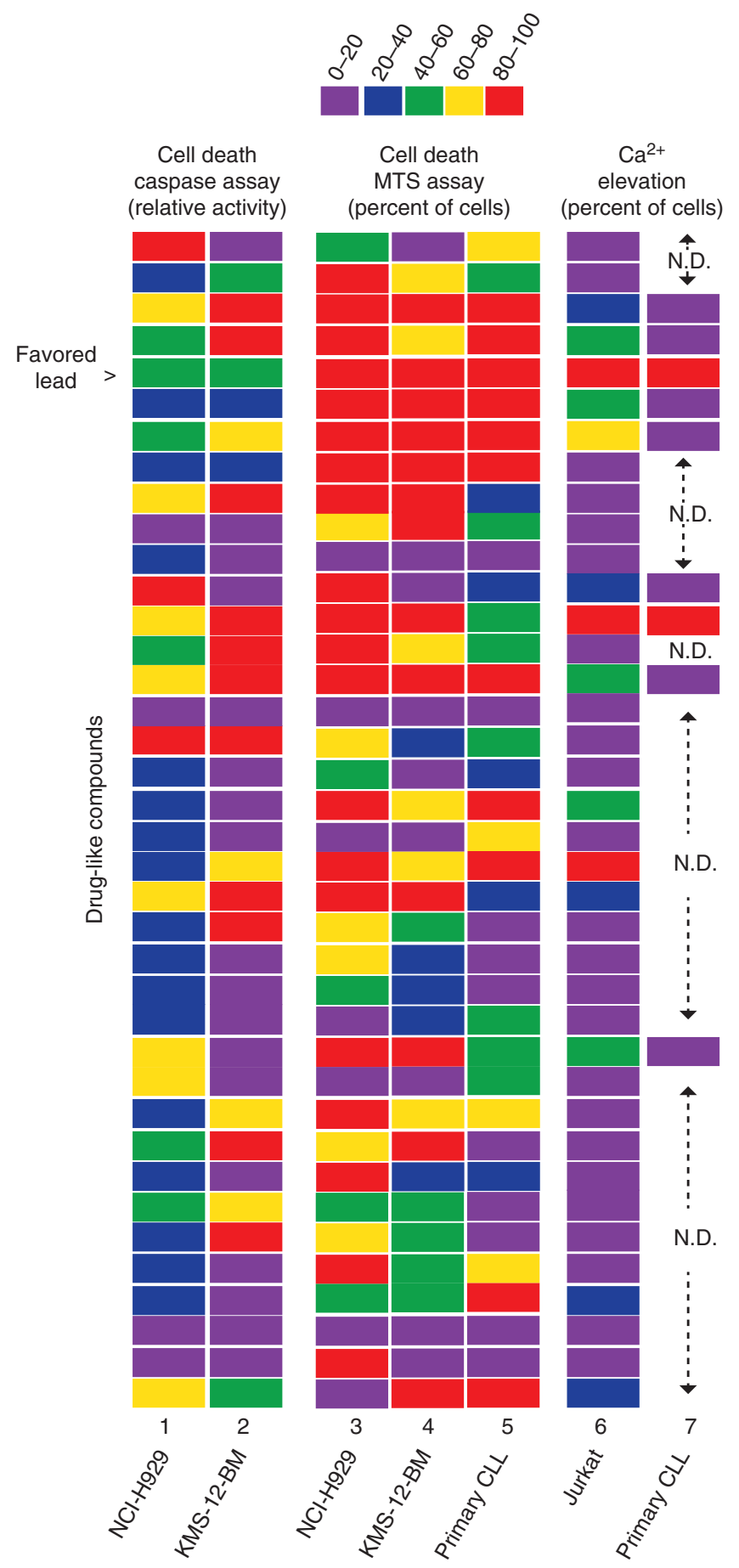

Figure 3. Heat map. This diagram reveals the relative significance of 38 drug-like compounds. The compound marked lead compound is the most impressive, in that it induces cell death, as detected by caspase assay and by MTS assay, and also induces $\mathrm{Ca}^{2+}$ elevation in both primary human chronic lymphocytic leukemia (CLL) cells and in the Jurkat cell line. In this way this lead compound mimics BIRD-2. Additional experiments not shown here indicate this compound also inhibits Bcl-2's interaction with $\mathrm{IP}_{3} \mathrm{Rs}$, a hallmark of BIRD-2 activity. 


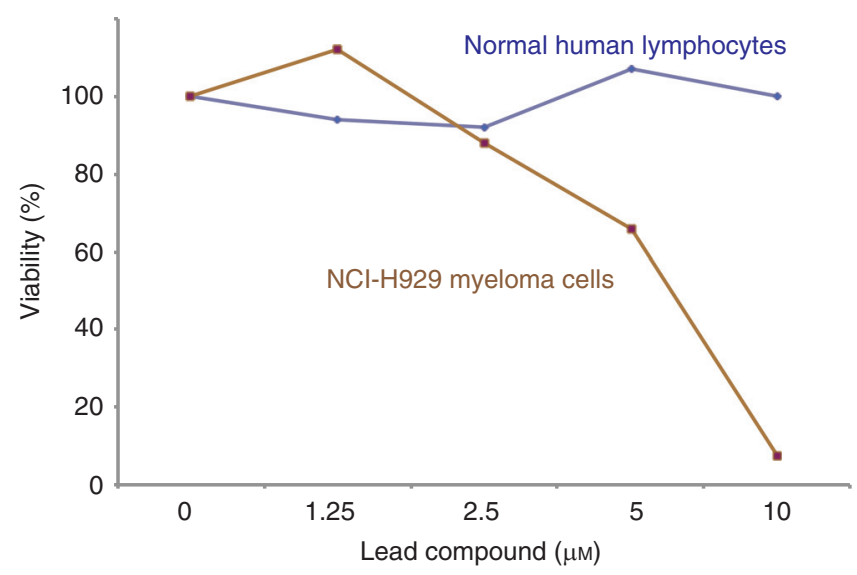

Figure 4. Cell death induction. Whereas the lead compound induces apoptosis in multiple myeloma cells, it does not decrease survival of normal human lymphocytes. This is further indication that this lead compound behaves like BIRD-2.

by promoting substantial elevation of cytosolic $\mathrm{Ca}^{2+}$ concentration, or by causing Bim expression and consequent sensitivity to ABT-199/ Venetoclax. For these reasons, developing a small molecule that mimics the action of BIRD-2 should be a high priority for both biomedical and pharmaceutical enterprises. The preliminary findings presented here provide strong rationale for this.

\section{CONCLUDING REMARKS}

Cancer cells of many types have aberrantly high amounts of $\mathrm{Bcl}-2$ promoting their survival. Although ABT-199/Venetoclax kills some of these cells, specifically those addicted to Bcl-2 for their survival, it is far from being fully effective. A growing number of studies have shown that disruption of the $\mathrm{Bcl}-2 / \mathrm{IP}_{3} \mathrm{R}$ interaction using BIRD-2, or an analogous tool, can promote cancer death. These observations highlight an alternative potential mechanism for killing cancers cells that are supported by high levels of Bcl-2 expression. More work is required to establish exactly how BIRD-2 kills cells and what prevailing conditions are necessary for BIRD-2 to be effective. Current evidence points to the factors such as constitutive $\mathrm{IP}_{3}$ production, $\mathrm{Ca}^{2+}$ influx, type $2 \mathrm{IP}_{3} \mathrm{Rs}$, mitochondrial $\mathrm{Ca}^{2+}$ sequestration and/or Bim expression for effective cancer cell killing by BIRD-2 (see Kerkhofs et al. 2019 for further discussion). Moreover, it seems that BIRD-2 is unlikely to be always effective as monotherapy, and may work efficaciously in conjunction with other anticancer treatments such as ABT-199/Venetoclax and cisplatin. However, the option of treating cancer with

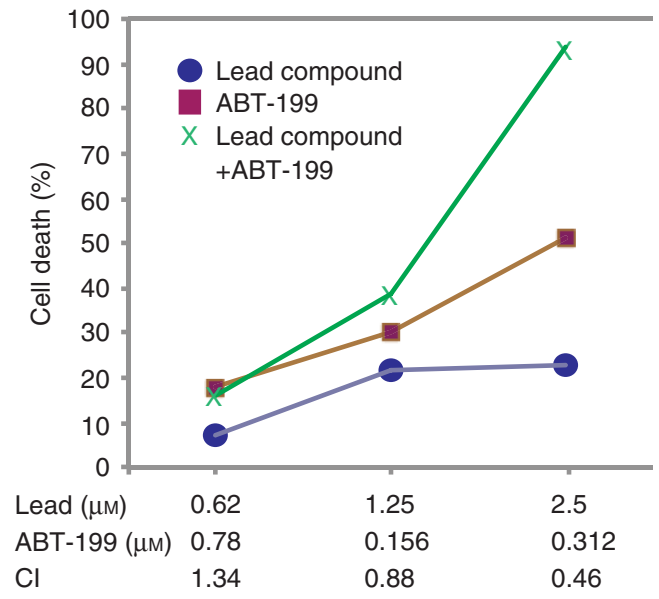

Figure 5. Synergy between the lead compound and ABT-199. KMS-12-BM myeloma cells were treated for 24 hours with the lead compound and ABT-199. Cell viability was measured by CAT assay and analyzed by Chou and Talaly method in which a combination index $(\mathrm{CI})$ value less than one defines synergy. Symbols represent triplicate determinations in a single experiment. 
agents that counter $\mathrm{Bcl}-2 / \mathrm{IP}_{3} \mathrm{R}$ interactions is now clearly in our grasp based on findings established using BIRD-2 and its analogs, as is the possibility of developing a therapeutic chemical compound that mimics BIRD-2's mode of action.

\section{ACKNOWLEDGMENTS}

This work was supported in part by the August J. and Karen A. Coppola Charitable Trust, the Charles S. Britton II Endowed Chair in Hematology/Oncology, the Harrington Discovery Institute of University Hospitals Cleveland Medical Center, the Council to Advance Human Health at Case Western Reserve University School of Medicine, National Institutes of Health Grants 1R21CA186912 and RO1 CA085804, and the American Society of Hematology Bridge Grant.

\section{REFERENCES}

Akl H, Monaco G, La Rovere R, Welkenhuyzen K, Kiviluoto S, Vervliet T, Molgó J, Distelhorst CW, Missiaen L, Mikoshiba K, et al. 2013. $\mathrm{IP}_{3} \mathrm{R} 2$ levels dictate the apoptotic sensitivity of diffuse large B-cell lymphoma cells to an $\mathrm{IP}_{3} \mathrm{R}$-derived peptide targeting the $\mathrm{BH} 4$ domain of $\mathrm{Bcl}-$ 2. Cell Death Dis 4: e632. doi:10.1038/cddis.2013.140

Andjelic S, Jain N, Nikolic-Zugic J. 1993. Immature thymocytes become sensitive to calcium-mediated apoptosis with the onset of $\mathrm{CD} 8, \mathrm{CD} 4$, and the $\mathrm{T}$ cell receptor expression: A role for bcl-2? J Exp Med 178: 1745-1751. doi:10.1084/jem.178.5.1745

Aouacheria A, Rech de Laval V, Combet C, Hardwick JM. 2013. Evolution of Bcl-2 homology motifs: Homology versus homoplasy. Trends Cell Biol 23: 103-111. doi:10 $.1016 /$ j.tcb.2012.10.010

Baffy G, Miyashita T, Williamson JR, Reed JC. 1993. Apoptosis induced by withdrawal of interleukin-3 (IL-3) from an IL-3-dependent hematopoietic cell line is associated with repartitioning of intracellular calcium and is blocked by enforced Bcl-2 oncoprotein production. J Biol Chem 268: 6511-6519.

Bakshi A, Jensen JP, Goldman P, Wright JJ, McBride OW, Epstein AL, Korsmeyer SJ. 1985. Cloning the chromosomal breakpoint of $t(14 ; 18)$ human lymphomas: Clustering around $\mathrm{JH}$ on chromosome 14 and near a transcriptional unit on 18. Cell 41: 899-906. doi:10.1016/ S0092-8674(85)80070-2

Barclay LA, Wales TE, Garner TP, Wachter F, Lee S, Guerra RM, Stewart ML, Braun CR, Bird GH, Gavathiotis E, et al. 2015. Inhibition of pro-apoptotic BAX by a noncanonical interaction mechanism. Mol Cell 57: 873-886. doi:10 .1016/j.molcel.2015.01.014
Berridge MJ. 1997. Lymphocyte activation in health and disease. Crit Rev Immunol 17: 155-178. doi:10.1615/Cri tRevImmunol.v17.i2.30

Berridge MJ. 2009. Inositol trisphosphate and calcium signalling mechanisms. Biochim Biophys Acta 1793: 933940. doi:10.1016/j.bbamcr.2008.10.005

Berridge MJ. 2016. The inositol trisphosphate/calcium signaling pathway in health and disease. Physiol Rev 96: 1261-1296. doi:10.1152/physrev.00006.2016

Bittremieux M, La Rovere RM, Akl H, Martines C, Welkenhuyzen K, Dubron K, Baes M, Janssens A, Vandenberghe P, Laurenti L, et al. 2018a. Constitutive $\mathrm{IP}_{3}$ signaling underlies the sensitivity of B-cell cancers to the $\mathrm{Bcl}-2 / \mathrm{IP}_{3}$ receptor disruptor BIRD-2. Cell Death Differ 26: 531547. doi:10.1038/s41418-018-0142-3

Bittremieux M, La Rovere RM, Schuermans M, Luyten T, Mikoshiba K, Vangheluwe P, Parys JB, Bultynck G. 2018b. Extracellular and ER-stored $\mathrm{Ca}^{2+}$ contribute to BIRD-2induced cell death in diffuse large B-cell lymphoma cells. Cell Death Discov 4: 101. doi:10.1038/s41420-018-0118-6

Bodnar D, Chung W Y, Yang D, Hong JH, Jha A, Muallem S. 2017. STIM-TRP pathways and microdomain organization: $\mathrm{Ca}^{2+}$ influx channels: The Orai-STIM1-TRPC complexes. Adv Exp Med Biol 993: 139-157. doi:10.1007/9783-319-57732-6_8

Bootman MD, Rietdorf K. 2017. Tissue specificity: Storeoperated $\mathrm{Ca}^{2+}$ entry in cardiac myocytes. Adv Exp Med Biol 993: 363-387. doi:10.1007/978-3-319-57732-6_19

Bultynck G, Vermassen E, Szlufcik K, De Smet P, Fissore RA, Callewaert G, Missiaen L, De Smedt H, Parys JB. 2003. Calcineurin and intracellular $\mathrm{Ca}^{2+}$-release channels: Regulation or association? Biochem Biophys Res Commun 311: 1181-1193. doi:10.1016/j.bbrc.2003.08.084

Cante-Barrett K, Gallo EM, Winslow MM, Crabtree GR. 2006. Thymocyte negative selection is mediated by protein kinase $\mathrm{C}$ - and $\mathrm{Ca}^{2+}$-dependent transcriptional induction of Bim of cell death. J Immunol 176: 2299-2306. doi:10.4049/jimmunol.176.4.2299

Chang MJ, Zhong F, Lavik AR, Parys JB, Berridge MJ, Distelhorst CW. 2014. Feedback regulation mediated by Bcl2 and DARPP-32 regulates inositol 1,4,5-trisphosphate receptor phosphorylation and promotes cell survival. Proc Natl Acad Sci 111: 1186-1191. doi:10.1073/pnas .1323098111

Chen R, Valencia I, Zhong F, McColl KS, Roderick HL, Bootman MD, Berridge MJ, Conway SJ, Holmes AB, Mignery GA, et al. 2004. Bcl-2 functionally interacts with inositol 1,4,5-trisphosphate receptors to regulate calcium release from the ER. J Cell Biol 166: 193-203. doi:10.1083/jcb .200309146

Chipuk JE, Moldoveanu T, Llambi F, Parsons MJ, Green DR. 2010. The BCL-2 family reunion. Mol Cell 37: 299-310. doi:10.1016/j.molcel.2010.01.025

Choudhary GS, Al-Harbi S, Mazumder S, Hill BT, Smith MR, Bodo J, Hsi ED, Almasan A. 2015. MCL-1 and BCL-xL-dependent resistance to the BCL-2 inhibitor ABT-199 can be overcome by preventing PI3K/AKT/ mTOR activation in lymphoid malignancies. Cell Death Dis 6: e1593. doi:10.1038/cddis.2014.525

Cimmino A, Calin GA, Fabbri M, Iorio MV, Ferracin M, Shimizu M, Wojcik SE, Aqeilan RI, Zupo S, Dono M, et al. 2005. miR-15 and miR-16 induce apoptosis by target- 
ing BCL2. Proc Natl Acad Sci 102: 13944-13949. doi:10 $.1073 /$ pnas.0506654102

Cleary ML, Smith SD, Sklar J. 1986. Cloning and structural analysis of cDNAs for $b c l-2$ and a hybrid $b c l-2 /$ immunoglobulin transcript resulting from the $t(14 ; 18)$ translocation. Cell 47: 19-28. doi:10.1016/0092-8674(86)90362-4

Davids MS, Letai A. 2013. ABT-199: Taking dead aim at BCL-2. Cancer Cell 23: 139-141. doi:10.1016/j.ccr.2013 .01 .018

Davids MS, Deng J, Wiestner A, Lannutti BJ, Wang L, Wu CJ, Wilson WH, Brown JR, Letai A. 2012. Decreased mitochondrial apoptotic priming underlies stroma-mediated treatment resistance in chronic lymphocytic leukemia. Blood 120: 3501-3509. doi:10.1182/blood-2012-02414060

Deng J, Carlson N, Takeyama K, Dal Cin P, Shipp M, Letai A. 2007. BH3 profiling identifies three distinct classes of apoptotic blocks to predict the response to ABT-737 and conventional chemotherapeutic agents. Cancer Cell 12: 171-185. doi:10.1016/j.ccr.2007.07.001

Ding J, Zhang Z, Roberts GJ, Falcone M, Miao Y, Shao Y, Zhang XC, Andrews DW, Lin J. 2010. Bcl-2 and Bax interact via the $\mathrm{BH} 1-3$ groove- $\mathrm{BH} 3$ motif interface and a novel interface involving the BH4 motif. J Biol Chem 285: 28749-28763. doi:10.1074/jbc.M110.148361

Distelhorst CW. 2018. Targeting Bcl-2-IP 3 receptor interaction to treat cancer: A novel approach inspired by nearly a century treating cancer with adrenal corticosteroid hormones. Biochim Biophys Acta Mol Cell Res 1865: 1795 1804. doi:10.1016/j.bbamcr.2018.07.020

Distelhorst CW, Bootman MD. 2011. Bcl-2 interaction with the inositol 1,4,5-trisphosphate receptor: Role in $\mathrm{Ca}^{2+}$ signaling and disease. Cell Calcium 50: 234-241. doi:10 .1016/j.ceca.2011.05.011

Eckenrode EF, Yang J, Velmurugan GV, Foskett JK, White C. 2010. Apoptosis protection by Mcl-1 and Bcl-2 modulation of inositol 1,4,5-trisphosphate receptor-dependent $\mathrm{Ca}^{2+}$ signaling. J Biol Chem 285: 13678-13684. doi:10 $.1074 /$ jbc.M109.096040

Erin N, Billingsley ML. 2004. Domoic acid enhances Bcl-2calcineurin-inositol-1,4,5-trisphosphate receptor interactions and delayed neuronal death in rat brain slices. Brain Res 1014: 45-52. doi:10.1016/j.brainres.2004.03 .076

Erin N, Bronson SK, Billingsley ML. 2003a. Calcium-dependent interaction of calcineurin with $\mathrm{Bcl}-2$ in neuronal tissue. Neuroscience 117: 541-555. doi:10.1016/S03064522(02)00933-8

Erin N, Lehman RAW, Boyer PJ, Billingsley ML. 2003b. In vitro hypoxia and excitotoxicity in human brain induce calcineurin-Bcl-2 interactions. Neuroscience 117: $557-$ 565. doi:10.1016/S0306-4522(02)00934-X

Fracchia KM, Pai CY, Walsh CM. 2013. Modulation of T cell metabolism and function through calcium signaling. Front Immunol 4: 324. doi:10.3389/fimmu.2013.00324

Gallo EM, Canté-Barrett K, Crabtree GR. 2006. Lymphocyte calcium signaling from membrane to nucleus. Nat Immunol 7: 25-32. doi:10.1038/ni1295

Gibson CJ, Davids MS. 2015. BCL-2 antagonism to target the intrinsic mitochondrial pathway of apoptosis. Clin Cancer Res 21: 5021-5029. doi:10.1158/1078-0432.CCR-150364
Gratiot-Deans J, Ding L, Turka LA, Nunez G. 1993. bcl-2 proto-oncogene expression during human $\mathrm{T}$ cell development. J Immunol 151: 83-91.

Greenberg EF, Lavik AR, Distelhorst CW. 2014. Bcl-2 regulation of the inositol 1,4,5-trisphosphate receptor and calcium signaling in normal and malignant lymphocytes: Potential new target for cancer treatment. Biochim Biophys Acta 1843: 2205-2210. doi:10.1016/j.bbamcr.2014 .03 .008

Greenberg EF, McColl KS, Zhong F, Wildey G, Dowlati A, Distelhorst CW. 2015. Synergistic killing of human small cell lung cancer cells by the Bcl-2-inositol 1,4,5-trisphosphate receptor disruptor BIRD-2 and the BH3-mimetic ABT-263. Cell Death Dis 6: e2034. doi:10.1038/cddis .2015 .355

Gross A. 2016. BCL-2 family proteins as regulators of mitochondria metabolism. Biochim Biophys Acta 1857: 12431246. doi:10.1016/j.bbabio.2016.01.017

Hajnóczky G, Csordás G, Krishnamurthy R, Szalai G. 2000. Mitochondrial calcium signaling driven by the $\mathrm{IP}_{3}$ receptor. J Bioenerg Biomembr 32: 15-25. doi:10.1023/A:100 5504210587

Hajnóczky G, Davies E, Madesh M. 2003. Calcium signaling and apoptosis. Biochem Biophys Res Commun 304: 445454. doi:10.1016/S0006-291X(03)00616-8

Hanson CJ, Distelhorst CW, Bootman MD, Berridge MJ, Roderick HL. 2004. Bcl-2 functionally interacts with the inositol 1,4,5-trisphosphate receptor $\left(\mathrm{Ins}_{3} \mathrm{R}\right)$ to inhibit calcium release. J Physiol 555P: PC69.

Hanson CJ, Bootman MD, Distelhorst CW, Roderick HL. 2008a. The cellular concentration of Bcl-2 determines its pro- and anti-apoptotic effect. Cell Calcium 44: 243-258. doi:10.1016/j.ceca.2007.11.014

Hanson CJ, Bootman MD, Distelhorst CW, Wojcikiewicz RJ, Roderick HL. 2008b. Bcl-2 suppresses $\mathrm{Ca}^{2+}$ release through inositol 1,4,5-trisphosphate receptors and inhibits $\mathrm{Ca}^{2+}$ uptake by mitochondria without affecting ER calcium store content. Cell Calcium 44: 324-338. doi:10 $.1016 /$ j.ceca.2008.01.003

He H, Lam M, McCormick TS, Distelhorst CW. 1997. Maintenance of calcium homeostasis in the endoplasmic reticulum by Bcl-2. J Cell Biol 138: 1219-1228. doi:10.1083/jcb .138 .6 .1219

Hockenberry DM, Zutter M, Hickey W, Nahm M, Korsmeyer SJ. 1991. BCL2 protein is topographically restricted in tissues characterized by apoptotic cell death. Proc Natl Acad Sci 88: 6961-6965. doi:10.1073/pnas.88.16.6961

Hogquist KA. 2001. Signal strength in thymic selection and lineage commitment. Curr Opinion Immunol 13: 225231. doi:10.1016/S0952-7915(00)00208-9

Hotchkiss RS, McConnell KW, Bullok K, Davis CG, Chang KC, Schwulst SJ, Dunne JC, Dietz GP, Bahr M, McDunn JE, et al. 2006. TAT-BH4 and TAT-Bcl- $\mathrm{x}_{\mathrm{L}}$ peptides protect against sepsis-induced lymphocyte apoptosis in vivo. $J$ Immunol 176: 5471-5477. doi:10.4049/jimmunol.176.9 .5471

Ivanova H, Ritaine A, Wagner L, Luyten T, Shapovalov G, Welkenhuyzen K, Seitaj B, Monaco G, De Smedt H, Prevarskaya $\mathrm{N}$, et al. 2016. The trans-membrane domain of Bcl-2 $\alpha$, but not its hydrophobic cleft, is a critical determinant for efficient $\mathrm{IP}_{3}$ receptor inhibition. Oncotarget 7: 55704-55720. doi:10.18632/oncotarget.11005 
Jakubowska MA, Kerkhofs M, Martines C, Efremov DG, Gerasimenko JV, Gerasimenko OV, Petersen OH, Bultynck G, Vervliet T, Ferdek PE. 2018. ABT-199 (Venetoclax), a BH3-mimetic Bcl-2 inhibitor, does not cause $\mathrm{Ca}^{2+}$-signalling dysregulation or toxicity in pancreatic acinar cells. Br J Pharmacol doi:10.1111/bph.14505

Joseph SK, Hajnóczky G. 2007. IP $_{3}$ receptors in cell survival and apoptosis: $\mathrm{Ca}^{2+}$ release and beyond. Apoptosis 12: 951-968. doi:10.1007/s10495-007-0719-7

Kerkhofs M, Vervloessem T, Bittremieux M, Bultynck G. 2019. Recent advances in uncovering the mechanisms contributing to BIRD-2-induced cell death in B-cell cancer cells. Cell Death Dis 10: 42. doi:10.1038/s41419-0181297-z

Konopleva M, Contractor R, Tsao T, Samudio I, Ruvolo PP, Kitada S, Deng X, Zhai D, Shi YX, Sneed T, et al. 2006. Mechanisms of apoptosis sensitivity and resistance to the BH3 mimetic ABT-737 in acute myeloid leukemia. Cancer Cell 10: 375-388. doi:10.1016/j.ccr.2006.10.006

Lam M, Dubyak G, Distelhorst CW. 1992. Mobilization of $\mathrm{Ca}^{2+}$ from the endoplasmic reticulum in glucocorticoidinduced apoptosis of mouse lymphoma cells. Blood 80: 430a.

Lam M, Dubyak G, Distelhorst CW. 1993. Effect of glucocorticosteroid treatment on intracellular calcium homeostasis in mouse lymphoma cells. Mol Endocrinol 7: 686693. doi:10.1210/mend.7.5.8316252

Lam M, Dubyak G, Chen L, Nuñez G, Miesfeld RL, Distelhorst CW. 1994. Evidence that BCL-2 represses apoptosis by regulating endoplasmic reticulum-associated $\mathrm{Ca}^{2+}$ fluxes. Proc Natl Acad Sci 91: 6569-6573. doi:10.1073/ pnas.91.14.6569

Lavik AR, Zhong F, Chang MJ, Greenberg E, Choudhary Y, Smith MR, McColl KS, Pink J, Reu FJ, Matsuyama S, et al 2015. A synthetic peptide targeting the BH4 domain of $\mathrm{Bcl}-2$ induces apoptosis in multiple myeloma and follicular lymphoma cells alone or in combination with agents targeting the BH3-binding pocket of Bcl-2. Oncotarget 6: 27388-27402. doi:10.18632/oncotarget.4489

Letai AG. 2008. Diagnosing and exploiting cancer's addiction to blocks in apoptosis. Nat Rev Cancer 8: 121-132. doi:10.1038/nrc2297

Lewis RS. 2003. Calcium oscillations in T-cells: Mechanisms and consequences for gene expression. Biochem Soc Trans 31: 925-929. doi:10.1042/bst0310925

Lin X, Várnai P, Csordás G, Balla A, Nagai T, Miyawaki A, Balla T, Hajnòczky G. 2005. Control of calcium signal propagation to the mitochondria by inositol $1,4,5$-trisphosphate-binding proteins. J Biol Chem 280: 1282012832. doi:10.1074/jbc.M411591200

Linette GP, Grusby MJ, Hedrick SM, Hansen TH, Glimcher LH, Korsmeyer SJ. 1994. Bcl-2 is upregulated at the $\mathrm{CD}^{+}$ $\mathrm{CD}^{+}$stage during positive selection and promotes thymocyte differentiation at several control points. Immunity 1: 197-205. doi:10.1016/1074-7613(94)90098-1

Mak DO, Foskett JK. 2015. Inositol 1,4,5-trisphosphate receptors in the endoplasmic reticulum: A single-channel point of view. Cell Calcium 58: 67-78. doi:10.1016/j.ceca .2014 .12 .008

McConkey DJ, Nicotera P, Hartzell P, Bellomo G, Wyllie AH, Orrenius S. 1989. Glucocorticoids activate a suicide process in thymocytes through an elevation of cytosolic
$\mathrm{Ca}^{2+}$ concentration. Arch Biochem Biophys 269: 365-370. doi:10.1016/0003-9861(89)90119-7

Monaco G, Decrock E, Akl H, Ponsaerts R, Vervliet T, Luyten T, De Maeyer M, Missiaen L, Distelhorst CW, De Smedt H, et al. 2012. Selective regulation of $\mathrm{IP}_{3}$-receptor-mediated $\mathrm{Ca}^{2+}$ signaling and apoptosis by the $\mathrm{BH} 4$ domain of Bcl-2 versus Bcl-Xl. Cell Death Differ 19: 295309. doi:10.1038/cdd.2011.97

Monaco G, Decrock E, Nuyts K, Wagner LE II, Luyten T, Strelkov SV, Missiaen L, De Borggraeve WM, Leybaert L, Yule DI, et al. 2013. $\alpha$-helical destabilization of the Bcl-2BH4-domain peptide abolishes its ability to inhibit the $\mathrm{IP}_{3}$ receptor. PLoS ONE 8: e73386. doi:10.1371/journal .pone.0073386

Monaco G, La Rovere R, Karamanou S, Welkenhuyzen K, Ivanova H, Vandermarliere E, Di Martile M, Del Bufalo D, De Smedt H, Parys JB, et al. 2018. A double point mutation at residues Ile14 and Val15 of Bcl-2 uncovers a role for the BH4 domain in both protein stability and function. FEBS J 285: 127-145. doi:10.1111/febs.14324

Neilson JR, Winslow MM, Hur EM, Crabtree GR. 2004. Calcineurin B1 is essential for positive but not negative selection during thymocyte development. Immunity 20: 255-266. doi:10.1016/S1074-7613(04)00052-4

Nougarède A, Rimokh R, Gillet G. 2018. BH4-mimetics and -antagonists: An emerging class of Bcl-2 protein modulators for cancer therapy. Oncotarget 9: 35291-35292. doi:10.18632/oncotarget.26250

Oakes SA, Scorrano L, Opferman JT, Bassik MC, Nishino M, Pozzan T, Korsmeyer SJ. 2005. Proapoptotic BAX and BAK regulate the type 1 inositol trisphosphate receptor and calcium leak from the endoplasmic reticulum. Proc Natl Acad Sci 102: 105-110. doi:10.1073/pnas.0408 352102

Pan R, Hogdal LJ, Benito JM, Bucci D, Han L, Borthakur G, Cortes J, DeAngelo DJ, Debose L, Mu H, et al. 2014 Selective BCL-2 inhibition by ABT-199 causes on-target cell death in acute myeloid leukemia. Cancer Discov 4: 362-375. doi:10.1158/2159-8290.CD-13-0609

Pettersson M, Jernberg-Wiklund H, Larsson LG, Sundstrom C, Givol I, Tsujimoto Y, Nilsson K. 1992. Expression of the bcl-2 gene in human multiple myeloma cell lines and normal plasma cells. Blood 79: 495-502.

Pinton P, Ferrari D, Rapizzi E, Di Virgilio F, Pozzan T, Rizzuto R. 2002. A role for calcium in Bcl-2 action? Biochimie 84: 195-201. doi:10.1016/S0300-9084(02)01373-1

Place AE, Goldsmith K, Bourquin JP, Loh ML, Gore L, Morgenstern DA, Sanzgiri Y, Hoffman D, Zhou Y, Ross JA, et al. 2018. Accelerating drug development in pediatric cancer: A novel phase I study design of Venetoclax in relapsed/refractory malignancies. Future Oncol 14: 21152129. doi:10.2217/fon-2018-0121

Prole DL, Taylor CW. 2016. Inositol 1,4,5-trisphosphate receptors and their protein partners as signalling hubs. $J$ Physiol 594: 2849-2866. doi:10.1113/JP271139

Putney JW. 2007. New molecular players in capacitative $\mathrm{Ca}^{2+}$ entry. J Cell Sci 120: 1959-1965. doi:10.1242/jcs.03462

Putney JW, Steinckwich-Besancon N, Numaga-Tomita T, Davis FM, Desai PN, D’Agostin DM, Wu S, Bird GS. 2017. The functions of store-operated calcium channels. Biochim Biophys Acta Mol Cell Res 1864: 900-906. doi:10 .1016/j.bbamcr.2016.11.028 
Rong Y, Distelhorst CW. 2008. Bcl-2 protein family members: Versatile regulators of calcium signaling in cell survival and apoptosis. Annu Rev Physiol 70: 73-91. doi:10 .1146/annurev.physiol.70.021507.105852

Rong Y, Aromolaran AS, Bultynck G, Zhong F, Li X, McColl KS, Herlitze S, Matsuyama S, Roderick HL, Bootman MD, et al. 2008. Targeting $\mathrm{Bcl}-2-\mathrm{IP}_{3}$ receptor interaction to reverse Bcl-2's inhibition of apoptotic calcium signals. Mol Cell 31: 255-265. doi:10.1016/j.molcel.2008.06.014

Rong Y, Bultynck G, Aromolaran AS, Zhong F, Parys JB, De Smedt H, Mignery GA, Roderick HL, Bootman MD, Distelhorst CW. 2009. The BH4 domain of Bcl-2 inhibits ER calcium release and apoptosis by binding the regulatory and coupling domain of the $\mathrm{IP}_{3}$ receptor. Proc Natl Acad Sci 106: 14397-14402. doi:10.1073/pnas.0907555106

Shibasaki F, Kondo E, Akagi T, McKeon F. 1997. Suppression of signalling through transcription factor NF-AT by interactions between calcineurin and Bcl-2. Nature 386: 728-731. doi:10.1038/386728a0

Siegel RM, Katsumata M, Miyashita T, Louie DC, Greene MI, Reed JC. 1992. Inhibition of thymocyte apoptosis and negative antigenic selection in bcl-2 transgenic mice. Proc Natl Acad Sci 89: 7003-7007. doi:10.1073/pnas.89.15 .7003

Sobecks RM, McCormick TS, Distelhorst CW. 1996. The imidazole antifungals miconazole and econazole induce apoptosis in mouse and human lymphoid leukemia cells. Cell Death Differ 3: 331-337.

Strasser A, Harris AW, Cory S. 1991. bcl-2 transgene inhibits T cell death and perturbs thymic self-censorship. Cell 67: 889-899. doi:10.1016/0092-8674(91)90362-3

Strasser A, Harris AW, von Boehmer H, Cory S. 1994. Positive and negative selection of $\mathrm{T}$ cells in T-cell receptor transgenic mice expressing a bcl-2 transgene. Proc Natl Acad Sci 91: 1376-1380. doi:10.1073/pnas.91.4.1376

Svenningsson P, Nishi A, Fisone G, Girault JA, Nairn AC, Greengard P. 2004. DARPP-32: An integrator of neurotransmission. Annu Rev Pharmacol Toxicol 44: 269-296. doi:10.1146/annurev.pharmtox.44.101802.121415

Szalai G, Krishnamurthy R, Hajnóczky G. 1999. Apoptosis driven by $\mathrm{IP}_{3}$-linked mitochondrial calcium signals. EMBO J 18: 6349-6361. doi:10.1093/emboj/18.22.6349

Tang TS, Bezprozvanny I. 2004. Dopamine receptor-mediated $\mathrm{Ca}^{2+}$ signaling in striatal medium spiny neurons. J Biol Chem 279: 42082-42094. doi:10.1074/jbc.M40 7389200

Tang TS, Tu H, Wang Z, Bezprozvanny I. 2003. Modulation of type 1 inositol $(1,4,5)$-trisphosphate receptor function by protein kinase A and protein phosphatase $1 \alpha$. J Neurosci 23: 403-415. doi:10.1523/jneurosci.23-02-00403.2003

Thomenius MJ, Wang NS, Reineks EZ, Wang Z, Distelhorst CW. 2003. Bcl-2 on the endoplasmic reticulum regulates Bax activity by binding to BH3-only proteins. J Biol Chem 278: 6243-6250. doi:10.1074/jbc.M208878200

Touzeau C, Dousset C, Le Gouill S, Sampath D, Leverson JD, Souers AJ, Maïga S, Béné MC, Moreau P, Pellat-Deceunynck $\mathrm{C}$, et al. 2014. The Bcl-2 specific $\mathrm{BH} 3$ mimetic ABT-199: A promising targeted therapy for $\mathrm{t}(11 ; 14) \mathrm{mul}$ tiple myeloma. Leukemia 28: 210-212. doi:10.1038/leu .2013 .216

Tsujimoto Y, Croce CM. 1986. Analysis of the structure, transcripts, and protein products of $b c l-2$, the gene in- volved in human follicular lymphoma. Proc Natl Acad Sci 83: 5214-5218. doi:10.1073/pnas.83.14.5214

Tsujimoto Y, Finger LR, Yunis J, Nowell PC, Croce CM. 1984. Cloning of the chromosome breakpoint of neoplastic B cells with the $t(14 ; 18)$ chromosome translocation. Science 226: 1097-1099. doi:10.1126/science.6093263

Tu H, Ts T, Wang Z, Bezprozvanny I. 2004. Association of type 1 inositol 1,4,5-trisphosphate receptor with AKAP9 (Yotiao) and protein kinase A. J Biol Chem 279: 1937519382. doi:10.1074/jbc.M313476200

Vaux DL, Cory S, Adams J. 1988. Bcl-2 gene promotes haemopoietic cell survival and co-operates with $c-m y c$ to immortalize pre-B cells. Nature 335: 440-442. doi:10 $.1038 / 335440 \mathrm{a} 0$

Veis DJ, Sentman CL, Bach EA, Korsmeyer SJ. 1993a. Expression of the Bcl-2 protein in murine and human thymocytes and in peripheral T lymphocytes. $J$ immunol 151: 2546-2554.

Veis DJ, Sorenson CM, Shutter JR, Korsmeyer SJ. 1993b. Bcl2-deficient mice demonstrate fulminant lymphoid apoptosis, polycystic kidneys, and hypopigmented hair. Cell 75: 229-240. doi:10.1016/0092-8674(93)80065-M

Vervliet T, Parys JB, Bultynck G. 2016. Bcl-2 proteins and calcium signaling: complexity beneath the surface. Oncogene 35: 5079-5092. doi:10.1038/onc.2016.31

Vervloessem T, Akl H, Tousseyn T, De Smedt H, Parys JB, Bultynck G. 2017a. Reciprocal sensitivity of diffuse large B-cell lymphoma cells to Bcl-2 inhibitors BIRD-2 versus venetoclax. Oncotarget 8: 111656-111671. doi:10.18632/ oncotarget.22898

Vervloessem T, Ivanova H, Luyten T, Parys JB, Bultynck G. 2017b. The selective Bcl-2 inhibitor venetoclax, a BH3 mimetic, does not dysregulate intracellular $\mathrm{Ca}^{2+}$ signaling. Biochim Biophys Acta Mol Cell Res 1864: 968-976. doi:10.1016/j.bbamcr.2016.11.024

Vervloessem T, Kerkhofs M, La Rovere RM, Sneyers F, Parys JB, Bultynck G. 2018. Bcl-2 inhibitors as anti-cancer therapeutics: The impact of and on calcium signalling. Cell Calcium 70: 102-116. doi:10.1016/j.ceca.2017.05.014

Volpe P, Alderson-Lang BH. 1990. Regulation of inositol 1,4,5-trisphosphate-induced $\mathrm{Ca}^{2+}$ release. II: Effect of cAMP-dependent protein kinase. Am J Physiol 258: C1086-C1091. doi:10.1152/ajpcell.1990.258.6.C1086

Wagner LE, Li WH, Yule DI. 2003. Phosphorylation of type1 inositol 1,4,5-trisphosphate receptors by cyclic nucleotide-dependent protein kinases. J Biol Chem 278: 4581145817. doi:10.1074/jbc.M306270200

Wagner LE, Joseph SK, Yule DI. 2008. Regulation of single inositol 1,4,5-trisphosphate receptor channel activity by protein kinase A phosphorylation. J Physiol 586: 35773596. doi:10.1113/jphysiol.2008.152314

Walaas SI, Hemmings HC Jr, Greengard P, Nairn AC. 2011. Beyond the dopamine receptor: Regulation and roles of serine/threonine protein phosphatases. Front Neuroanat 5: 1-17. doi:10.3389/fnana.2011.00050

Wang NS, Unkila M, Reineks EZ, Distelhorst CW. 2001. Transient expression of wild-type or mitochondrially targeted Bcl-2 induced apoptosis, whereas transient expression of endoplasmic reticulum-targeted $\mathrm{Bcl}-2$ is protective against Bax-induced cell death. J Biol Chem 276: 44117-44128. doi:10.1074/jbc.M101958200 
C.W. Distelhorst and M.D. Bootman

Warren C, Vilain RE, Ashton KA, Almazi GJ, Braye S, Moscato P, Bowden NA. 2016. The rare BCL-2 isoform $\mathrm{BCL}-2 \beta$ is associated with melanoma survival and the apoptotic response to UV and cisplatin. Cancer Res 76: 3559. doi:10.1158/1538-7445.AM2016-3559

White C, Li C, Yang J, Petrenko NB, Madesh M, Thompson CB, Foskett JK. 2005. The endoplasmic reticulum gateway to apoptosis by Bcl- $\mathrm{X}_{\mathrm{L}}$ modulation of the $\mathrm{InsP}_{3} \mathrm{R}$. Nat Cell Biol 7: 1021-1028. doi:10.1038/ncb1302

Xie Q, Xu Y, Gao W, Zhang Y, Su J, Liu Y, Guo Y, Dou M, Hu K, Sun L. 2018. TA-fused $\mathrm{IP}_{3} \mathrm{R}$-derived peptide enhances cisplatin sensitivity of ovarian cancer cells by increasing $\mathrm{ER} \mathrm{Ca}^{2+}$ release. Int J Mol Med 41: 809-817.

Xu L, Kong D, Zhu L, Zhu W, Andrews DW, Kuo TH. 2007. Suppression of $\mathrm{IP}_{3}$-mediated calcium release and apoptosis by Bcl-2 involves the participation of protein phosphatase 1. Mol Cell Biochem 295: 153-165. doi:10.1007/ s11010-006-9285-5

Yip KW, Reed JC. 2008. Bcl-2 family proteins and cancer. Oncogene 27: 6398-6406. doi:10.1038/onc.2008.307

Youle RJ, Strasser A. 2008. The Bcl-2 protein family: Opposing activities that mediate cell death. Nat Rev Mol Cell Biol 9: 47-59. doi:10.1038/nrm 2308
Zhang QH, Sheng HP, Loh TT. 2001. bcl-2 protects HL-60 cells from apoptosis by stabilizing their intracellular calcium pools. Life Sci 68: 2873-2883. doi:10.1016/S00243205(01)01073-6

Zhong F, Davis MC, McColl KS, Distelhorst CW. 2006. Bcl-2 differentially regulates $\mathrm{Ca}^{2+}$ signals according to the strength of $\mathrm{T}$ cell receptor activation. J Cell Biol 172: 127-137. doi:10.1083/jcb.200506189

Zhong F, Harr MW, Bultynck G, Monaco G, Parys JB, DeSmedt H, Rong Y-P, Molitoris JK, Lam M, Ryder C, et al. 2011. Induction of $\mathrm{Ca}^{2+}$-driven apoptosis in chronic lymphocytic leukemia cells by peptide-mediated disruption of Bcl-2- $\mathrm{IP}_{3}$ receptor interaction. Blood 117: 29242934. doi:10.1182/blood-2010-09-307405

Zhu W, Cowie A, Wasfy GW, Penn LZ, Leber B, Andrews DW. 1996. Bcl-2 mutants with restricted subcellular location reveal spatially distinct pathways for apoptosis in different cell types. EMBO J 15: 4130-4141. doi:10.1002/j .1460-2075.1996.tb00788.x

Zornig M, Busch G, Beneke R, Gulbins E, Lang F, Ma A, Korsmeyer S, Moroy T. 1995. Survival and death of prelymphomatous B-cells from N-myc/bcl-2 double transgenic mice correlates with the regulation of intracellular $\mathrm{Ca}^{2+}$ fluxes. Oncogene 11: 2165-2174. 


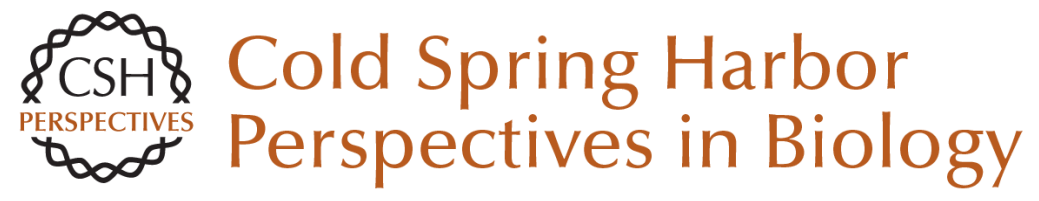

\title{
Creating a New Cancer Therapeutic Agent by Targeting the Interaction between Bcl-2 and IP 3 Receptors
}

\author{
Clark W. Distelhorst and Martin D. Bootman
}

Cold Spring Harb Perspect Biol 2019; doi: 10.1101/cshperspect.a035196 originally published online May 20, 2019

\section{Subject Collection Calcium Signaling}

The Endoplasmic Reticulum-Plasma Membrane Junction: A Hub for Agonist Regulation of $\mathrm{Ca}^{2+}$ Entry

Hwei Ling Ong and Indu Suresh Ambudkar

Calcium-Handling Defects and Neurodegenerative

Disease

Sean Schrank, Nikki Barrington and Grace E. Stutzmann

Lysosomal $\mathrm{Ca}^{2+}$ Homeostasis and Signaling in Health and Disease

Emyr Lloyd-Evans and Helen Waller-Evans

$\mathrm{Ca}^{2+}$ Signaling in Exocrine Cells

Malini Ahuja, Woo Young Chung, Wei-Yin Lin, et al.

Functional Consequences of Calcium-Dependent Synapse-to-Nucleus Communication: Focus on Transcription-Dependent Metabolic Plasticity Anna M. Hagenston, Hilmar Bading and Carlos Bas-Orth

Identifying New Substrates and Functions for an Old Enzyme: Calcineurin

Jagoree Roy and Martha S. Cyert

Fundamentals of Cellular Calcium Signaling: A

Primer

Martin D. Bootman and Geert Bultynck
Primary Active $\mathrm{Ca}^{2+}$ Transport Systems in Health and Disease

Jialin Chen, Aljona Sitsel, Veronick Benoy, et al.

Signaling through $\mathrm{Ca}^{2+}$ Microdomains from

Store-Operated CRAC Channels

Pradeep Barak and Anant B. Parekh

Structural Insights into the Regulation of $\mathrm{Ca}^{2+}$

/Calmodulin-Dependent Protein Kinase II (CaMKII) Moitrayee Bhattacharyya, Deepti Karandur and John Kuriyan

Store-Operated Calcium Channels: From Function

to Structure and Back Again Richard S. Lewis

Bcl-2-Protein Family as Modulators of $\mathrm{IP}_{3}$

Receptors and Other Organellar $\mathrm{Ca} 2+$ Channels Hristina Ivanova, Tim Vervliet, Giovanni Monaco, et al.

Calcium Signaling in Cardiomyocyte Function Guillaume Gilbert, Kateryna Demydenko, Eef Dries, et al.

Cytosolic $\mathrm{Ca}^{2+}$ Buffers Are Inherently $\mathrm{Ca}^{2+}$ Signal Modulators Beat Schwaller

For additional articles in this collection, see http://cshperspectives.cshlp.org/cgi/collection/

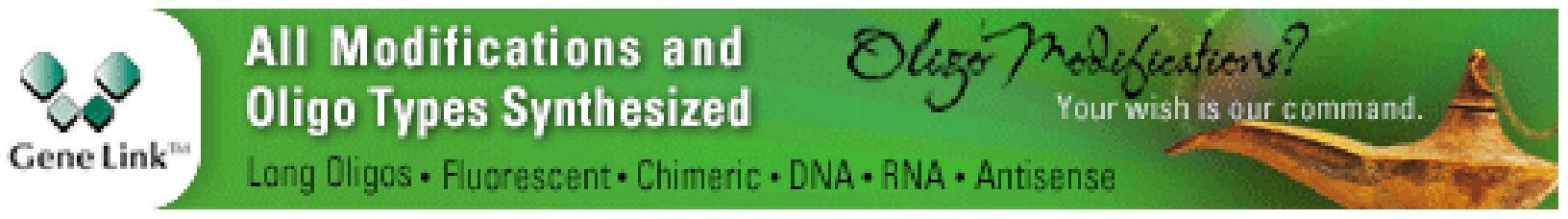


Role of Two-Pore Channels in Embryonic Development and Cellular Differentiation Sarah E. Webb, Jeffrey J. Kelu and Andrew L. Miller

\section{Organellar Calcium Handling in the Cellular \\ Reticular Network}

Wen-An Wang, Luis B. Agellon and Marek Michalak

For additional articles in this collection, see http://cshperspectives.cshlp.org/cgi/collection/

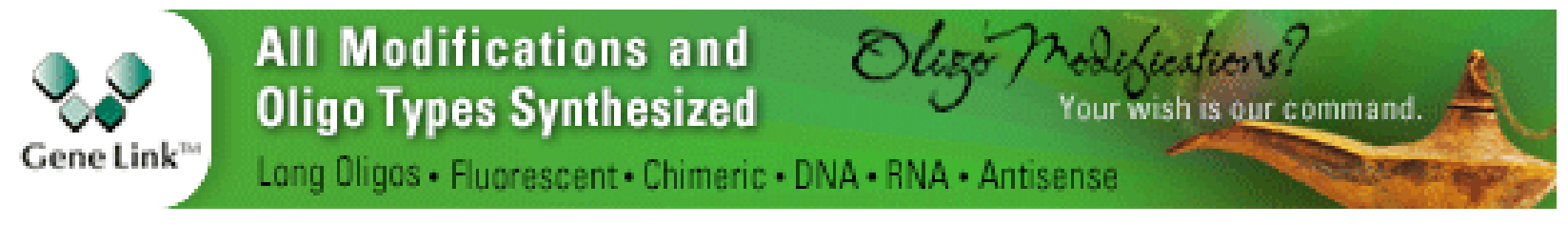

Copyright @ 2019 Cold Spring Harbor Laboratory Press; all rights reserved 